\title{
System of criminal legal principles
}

\author{
Oleg Valentinovich Strilets ${ }^{1 *}$, Victoria Vyacheslavovna Namnyaseva ${ }^{1}$, Vitaly Alekseevich \\ Kanubrikov $^{1}$, Irina Alisalamovna Niftalieva ${ }^{2}$, and Dmitry Vladimirovich Zhmurin ${ }^{2}$ \\ ${ }^{1}$ Volgograd Academy of the Ministry of the Interior of Russia, Department of Criminal Law, \\ Volgograd, Russia \\ ${ }^{2}$ Volgograd Academy of the Ministry of the Interior of Russia, Associate Postgraduate, Volgograd, \\ Russia
}

\begin{abstract}
Modern globalization processes consisting in transnational integration concern not only politics, economy, and culture but also the sphere of combating crime. In the fight against international criminal manifestations, it is necessary to consolidate powerful stabilising factors. One of these factors is criminal law principles, which are a kind of prism through which national legislation is assessed and the practice of its application is adjusted. In this regard, the question of systematising the principles of criminal law is of great importance. Purpose of the research: formulation of the authors' approach to the problem of systematisation of criminal law principles. Methods: the research was based on the general philosophical dialectical method of scientific knowledge. Besides, the historical and legal, structured system method and formal and logical methods were used. Results and novelty: resulting from the study, the authors' approach to the system of criminal law principles based on their interrelation, interdependence, and mutual influence is presented. The proposed separation of principles for the first time in the Russian criminal law doctrine reflects both horizontal and vertical classification. Horizontally, criminal law principles are divided into extraordinary (principle of justice), ordinary (principles of equality, humanism, and guilt), and substantive (principle of legality). The extraordinary principle of justice predetermines the content of other principles of criminal law. The ordinary principles of equality, humanism, and guilt determine the implementation of the principle of justice in criminal law. The substantive principle of legality is a unified basis for consolidating the provisions of the principles of criminal law in criminal legislation. This understanding of the principles of criminal law allows building their hierarchy. Vertically, the first place, due to its importance, is assigned to the principle of justice, the second belongs to the principle of equality, the third focuses on the principle of humanism, the fourth concentrates on the principle of guilt and, finally, the principle of legality completes the system.
\end{abstract}

Keywords: approach, classification, hierarchy

* Corresponding author: oleg-strilez@rambler.ru 


\section{Introduction}

In the context of the new geopolitical realities, the fight against crime presupposes the presence of clear guidelines in the field of regulation of criminal law relations. Criminal law principles are, of course, the most important of these guidelines. It is these fundamental ideas that should permeate the criminal legislation and form the basis of law enforcement [1]. "In the last decade", writes Bavsun, "it is becoming more and more obvious that the impact on crime cannot retain the previous forms" [2, p. 571]. In this regard, the problems arising from the implementation of criminal law principles impede the effectiveness of combating crime. Moreover, they lead to the pathology of law actually typified, as Namnyaseva states, "by a complex of interrelated and interdependent phenomena, by defectiveness of law-making, pathology of legal realisation and pathology of legal consciousness" [3, p. 86]. Thus, given the importance of these categories of criminal law, the formation of their system is of particular relevance.

The purpose of the study is to develop the authorial approach to the system of principles of criminal law which presupposes a clear position regarding their horizontal (endowing with certain characteristics) and vertical (building a hierarchy) division.

To achieve this goal, it is necessary to solve several problems, namely: to identify the views of Russian legal scholars [4-7], as well as foreign experts [8-11] on the problem of classification of criminal law principles and to analyse the interdependence of the principles enshrined in criminal law.

\section{Methods}

In the course of the study, the authors examined the scientific literature on the problems of the principles of criminal law, in particular, the issue of their systematisation. At the same time, both works of the Soviet period and modern sources were used.

\section{$3 \quad$ Results}

The authorial interdependent approach to the system of criminal law principles has been developed.

\section{Discussion}

In the scientific literature, there are many approaches to the system of criminal law principles. Thus, Zagorodnikov distinguishes two groups. The author includes general principles that are basic for all branches of law (legality, humanism, etc.) in the first group, and he subsumes industry-specific (special) ones, i.e. inherent in the main branch of criminal law (personal and guilty responsibility, individualisation of responsibility and punishment, etc.) under the second group [4].

Krieger, in addition to general and industry-specific, also identifies intersectoral principles of law. This group of principles, according to the legal expert, characterises the specifics of legal regulation in several related branches of law [5, p. 103-105]. Belyaev includes general legal, general criminal law, as well as special principles in the three-tier structure of criminal law principles [12, p. 40].

On the contrary, Naumov denies the need to single out special (industry-specific) principles of criminal law. The legal expert argues his point of view by the fact that general principles act directly through special ones, and special principles, in turn, are a refraction of general ones. This position, according to the scientist, "takes into account not only the process 
of differentiation of branches of law as a tendency in the development of its system but also the simultaneous process of their integration reflecting the opposite tendency. In this regard, most of the industry-specific principles have, as a rule, their analogs in other branches of law and cease to be purely special (industry-specific)" [13, pp. 73-74].

The next approach to the system of criminal law principles is based on their functional orientation. So, Fefelov divides the principles of criminal law into basic and regulatory. The first ones, according to the author's definition, "have a major significance since they operate throughout the entire period from the establishment of criminal punishability to the execution of punishment". These include: the inevitability and individualisation of punishment, humanism, democracy, and legality. Regulatory principles are those that operate at certain stages of the implementation of criminal law (compliance of punishment with the severity of the crime committed and the economy of repression) [14, p. 113].

Another classification of the principles of criminal law is formed taking into account the type and result of criminal-political activity. For example, Sabitov divides principles depending on the direction of criminal-legal political activity (dynamic component) and its normative-legal expression (static component). The author considers the following principles as dynamic: rule-making; criminalisation and decriminalisation, as well as penalisation and depenalisation of acts; qualifications of criminal acts; sentencing; criminal legal incentives. The principles of legality, guilty responsibility, proportionality, the inadmissibility of repeated responsibility for the same crime, humanism, equality of citizens before the law, personal responsibility, the inevitability of punishment, the expediency of applying criminal law measures, and moderation of criminal law influence are subsumed under the static form [7, pp. 192-359].

Of course, each of the presented approaches has some substance. At the same time, none of the authors builds a system of criminal law principles based on their interdependence. In addition, these items reflect only horizontal classification. In this regard, it is advisable to develop a system of principles of criminal law which, firstly, will be based on their interrelation, interdependence, and mutual influence, and, second, include both horizontal and vertical division.

The principles of criminal law are perceived as the main ideas developed by society and represent the basic principles and ideas about the system of values that determine the content and direction of criminal law as a whole. Regardless of whether the principles of law are enshrined or not in special articles of the law, they fully fulfil regulatory and protective functions. However, the very fact of declaring the principles in the norms of the Criminal Code of the Russian Federation (hereinafter referred to as the RF Criminal Code) undoubtedly increases their importance guaranteeing the protection and observance of basic social values in society. They, like other norms, are mandatory for all participants in criminal law relations.

In the current RF Criminal Code, the legislator has enshrined five principles: legality (Art. 3), equality of citizens before the law (Art. 4), guilt (Art. 5), justice (Art. 6), and humanism (Art. 7).

Considering the issue of the system of principles of criminal legislation, it is necessary to take into account the sequence of their participation in law enforcement. The principle of legality defines the scope of application of other criminal law principles. So, initially, a criminal law prohibition is determined, while the norm is adopted taking into account the legally defined principles. At the same time, pointing out the inadmissibility of applying the law by analogy (the principle of legality), this provision is associated both with the principle of justice providing connection only with legislatively specified crimes and exclusively by the people who committed them, and with the principle of guilt since does not allow strict liability. Then, in accordance with the principle of justice, in case of violation of the prohibition specified in the law, the general principles of individualisation of punishment and 
the application of other measures of a criminal-legal nature are determined contributing to the establishment of proportionality of the degree of social danger of the crime, the circumstances of its commission and the perpetrator. At the same time, in accordance with the principle of equality of all before the law, a person guilty of a crime is subject to responsibility regardless of gender, race, nationality, language, origin, property and official status, place of residence, attitude to religion, beliefs, membership of public associations, etc. The principle of humanism determining that the punishments and other measures of a criminal-legal nature provided for by the criminal law cannot be aimed at causing physical suffering or humiliation of human dignity fills the principle of legality with social content. The principles of justice, equality, guilt, and humanism predetermine the content of the criminal law norm, and the principle of legality in relation to them is official ensuring their accurate expression.

The connection between the principles of criminal law is carried out through a universal category, namely, justice. As Maltsev states, “... the principle of justice is the richest and broadest in social terms" [6, p. 141]. Agreeing with the opinion about the supremacy of the principle of justice, its extraordinariness, and meaning, the authors would like to note that it predetermines the content of ordinary principles, which include the principles of guilt, equality, and humanism. Accordingly, the latter, in turn, realising the equalising and distributing aspects of social justice, determine the content of the principle of guilt. The behaviour of a person at the moment of committing a socially dangerous act is based on a conscious, free, and equal choice, i.e. the subjective basis of the equality of citizens before the law. Therefore, the assessment of the behaviour of a person's committing a socially dangerous act should be based only on humane ideas inherent in this society [15, pp. 26-27].

The principle of legality as a single basis for the normative consolidation of the ideas expressed in these principles is, therefore, substantive.

\section{Conclusion}

The conducted research allows concluding that the principles of criminal law are a debatable category of modern criminal law doctrine. There is no consensus in the scientific community regarding their separation. Being intent on proving the social purpose of the principles of criminal law, many authors point to their certain specificity in the system of social control. However, the specialisation of the principles of criminal law in relation to various stages of the implementation of criminal responsibility is illegal since the Russian criminal legislation enshrines the principles that are universal for criminal law as a branch of law.

The principles of criminal law, due to their social and legal necessity, must be enshrined in legislation [16]. In the current Criminal Code of the Russian Federation, basic principles are formulated that are of the same mandatory practical nature as other norms.

The systematisation of the principles of criminal law should be based on their interrelation, interdependence, and mutual influence [17]. Horizontally, criminal law principles are divided into extraordinary (principle of justice), ordinary (principles of equality, humanism and guilt), and substantive (principle of legality). Vertically, first place is given to the principle of justice, second - to the principle of equality, third - to the principle of humanism, fourth - to the principle of guilt, and, finally, the principle of legality completes the system.

The problems of the principles of criminal law will always be relevant and especially important [18, p. 635]. According to the degree of implementation of these criminal law ideas, one can judge the effectiveness of the fight against crime in general, as well as the compliance of national criminal legislation with international standards in the field of protection of human rights and freedoms. 


\section{References}

1. V.I. Tretyakov, O.V. Strilets, Bulletin of the Volgograd Academy of the Ministry of Internal Affairs of Russia, 47(4), 9-13 (2018). https://doi.org/10.25724 / VAMVD.EBCD.

2. M.V. Bavsun, Russian Journal of Criminology, 14(4), 570-580 (2020). https://doi.org/10.17150/2500-4255.2020.14(4).570-580

3. V.V. Namnyaseva, Philosophy of Law, 82(3), 85-92 (2017)

4. N.I. Zagorodnikov, Soviet State and Law, 5, 71-74 (1966)

5. G.A. Krieger, Soviet State and Law, 2, 103-107 (1981)

6. V.V. Maltsev, Printsipy ugolovnogo prava i ikh realizatsiya v pravoprimenitelnoi deyatelnosti [The principles of criminal law and their implementation in law enforcement] (Yuridicheskii tsentr Press, Saint Petersburg, 2004)

7. T.R. Sabitov, Ugolovno-pravovye printsipy: ponyatie, sistema i vidy [Criminal law principles: concept, system and types], Doctoral thesis (Ural State Law University, Ekaterinburg, 2019)

8. J. Horder, Ashworth's principles of criminal law (Oxford University Press, New York, 2019)

9. M. Peno, Liverpool Law Rev. 40(2), 79-93 (2019). https://doi.org/10.1007/s10991019-09226-y

10. G. Werle, F. Jessberger, Principles of international criminal law (Oxford University Press, New York, 2020)

11. A. Završnik, Eur. J. Criminol. (2019). https://doi.org/10.1177/1477370819876762

12. N.A. Belyaev, Ugolovno-pravovaya politika i puti ee realizatsii [Criminal law policy and ways of its implementation] (Leningrad State University Publishing House, Leningrad, 1986)

13. A.V. Naumov, Rossiiskoe ugolovnoe pravo. Obshchaya chast: kurs lektsii [Russian criminal law. General part: a course of lectures] (Katalog, Moscow, 2020)

14. P.A. Fefelov, Mekhanizm ugolovno-pravovoi okhrany. Osnovnye metodologicheskie problem [The mechanism of criminal law protection. Main methodological problems] (Nauka, Moscow, 1992)

15. N.I. Lapin, Sociological Studies, 5, 23-34 (2016)

16. O. Oliinyk, O. Tatarov, V. Matsiuk, O. Vashchuk, A. Danylevskyi, J. Leg. Ethical Regul. Issues 23(2) (2020)

17. M. Wood, Int. Comm. Law Rev. 21(3-4), 307-324 (2019). https://doi.org/10.1163/18719732-12341404

18. R.V. Zhubrin, Russian Journal of Criminology, 10(4), 627-637 (2016). https://doi.org/10.17150/2500-4255.2016.10(4).627-637 